\title{
National Cultural Distance and International Acquisition Performance
}

\author{
Michael Akanni and Mohammad Ahammad
}

\begin{abstract}
This paper investigates the implications of national cultural distance on international acquisition performance, involving companies from England. It proposes recommendations for the managers of English companies in how to manage these differences effectively. In general, findings indicate that the differences in national culture obstruct integration capabilities, bringing about a negative indirect effect on acquisition performance. From these findings, our recommendations are established, which suggest that in order to succeed, management styles and communication strategies need to be adapted to suit the target firms culture. In addition trust must be developed amongst all members in order to reduce any resistance to change.
\end{abstract}

Index Terms-GLOBE index, international acquisitions, national culture, performance.

\section{INTRODUCTION}

Despite the recent economic downturn, cross border acquisitions remain popular strategies for English organizations, wishing to achieve corporate growth. Over the past decade, companies from the UK, involving England, continue to be highly active international acquirers, evident from the total value of transactions reaching $£ 50.8$ billion as recent as 2011 [1]. Yet, regardless of current trends, there has been increasing acknowledgment of the poor performance of many cross border transactions. Reference [2] reported that "64\% of all cross border mergers and acquisitions do not produce the expected benefits, whilst more than $50 \%$ do not even repay the investment". Whilst numerous factors are attributed to these failures, reference [3] states that the existence of national cultural distance has often been cited as a major reason for these outcomes. Consequently, an "us versus them mentality" arises, creating the potential for social conflict" [4]. Therefore, if differences between national cultures are among the main reasons for problems in international acquisitions, the main question that arises is what can be done to deal with these problems.

Previous M\&A studies, involving English companies, have already reported on national cultural distance and its impact on performance. However, most of these studies have been very selective, exploring activities with those companies mainly from developed economies. According to reference [5] companies from England are also heavily engaged in cross border acquisitions in developing and emerging markets. For that reason, this provides justification

Manuscript received October 5, 2013; revised November 13, 2013.

Michael Akanni is with the Nottingham Trent University, Burton Street, Nottingham, NG1 4BU, UK (e-mail: m.akanni@hotmail.com).

Mohammad F. Ahammad is with the Nottingham Business School, Nottingham Trent University, Burton Street, Nottingham, NG1 4BU, UK (e-mail: mohammad.ahammad@ntu.ac.uk). to focus attention on nations from these vicinities.

The aim of the paper is to investigate the impact of national cultural differences on international acquisition performance involving firms from England. This paper contributes in cross-cultural research in three ways. Firstly, as part of the due diligence process, it will measure cultural distance of firms from England with firms from all economies, which include those from developing and emerging markets. Secondly, through our pre-acquisition assessment, we will investigate the specific dimensions of national culture, where differences with other nations are extensive, thereafter exploring their implications on acquisition performance.

\section{LITERATURE REVIEW}

\section{A. National Cultural Distance as Source of Impediment}

Several studies report that national culture affects the extent to which acquisition partners interact and communicate during the post acquisition phase. Reference [6] explains that individuals from individualistic cultures are more interested in reminders and greetings and less interested in conversations and contacts. On the other hand, people from collectivist cultures are more inclined to communicate and forge cooperative alliances, [7]. Very distinct styles and expectations from communication among different national cultures often results in complexities in cooperation and sharing business ideas.

\section{B. National Cultural Distance as Source of development}

Whilst national cultural distance is frequently connected with poor performance, it can be strongly argued that, certain conditions allow for cultural distance to be a potential success factor in cross border deals. Reference [8] conceptualizes knowledge transfer as the beneficial use of capabilities, skills and knowledge from one organisation in another. Differences in national culture can be related to the "differences in the forms of knowledge that may be useful for the other party" [4]. So when cultural distance is retained, international acquisitions provide access to potentially valuable repository of capabilities such as resources, functional or management skills, [8]. When these capabilities are transferred between the organisations, a competitive advantage can be achieved and value is created. This reinforces how acquisitions that are culturally distant often result in positive outcomes.

Nevertheless, reference [9] states that although cultural differences provide the opportunities to realize learning, issues can still arise as to whether knowledge transferred has been assimilated. Therefore successful knowledge transfer depends to some extent on the receiving unit's absorptive capacity. Under conditions where the absorptive capacity of the receiver is high, they will have the ability to processes 
new information and apply it to the organization, to produce tangible results, [10]. It is under these circumstances, where national cultural distance will have a positive influence.

\section{RESEARCH METHODOLOGY}

The information collected to conduct this research is through secondary sources. The sources of evidence in the research include, the 'Globe studies nine dimensional data' [11]. The practice scores are used as it measures the actual distance rather than ideal differences. Other examples of sources of evidence include, a sampling frame, generated from the Mergers and Acquisitions Database of Thomson One Banker, regarding acquisitions involving English companies over a four year period.

The population of this research was any company in any country, where England had made an acquisition. However, due to the limited time frame, it is beyond the scope of this research to look at every single country. Therefore, we have used a selection criteria of the nations, English companies have been most active in. This was established by investigating the trends of English foreign acquisitions between the periods $2008-2012$ which resulted in a total sampling frame of 19 countries.

\section{FINDINGS}

We begin by presenting the recent trends in cross border acquisitions, involving English companies. This will help to justify and contextualize our research, in relation to our investigation into the national cultural distance between England and specific nations within the societal clusters.

Table I shows the distribution of English cross border. The trends prove that there is a large volume of cross-border acquisition deals taking place for English firms. For this reason, it has placed greater importance for English managers to ensure they manage cultural differences effectively. Based on the current levels of activity, we have arrived at a final sample, comprising of 19 nations in which English M\&As activity were most frequent. These countries within the sample are spread across nine country clusters according to GLOBE, as illustrated below in Table II.

\section{ANALYSIS AND DISCUSSION}

We focus on specific dimension of national culture in order to draw specific conclusions the effects differences in each dimension can have rather than investigating the overall cultural distance.

\section{A. Power Distance: Denmark and South Africa}

With reference to Table II, findings confirm that England scored amongst the highest within our sample, on the power distance dimension, with a practice score of 5.15. Reference [12] states that power distance in an organisational context, relates to the extent in which subordinates feel they can influence decisions made by superiors and participate in the decision making process.

Their score indicates that, within English companies, the status of superiors are important and should be respected by the subordinates "who usually expect clear instructions, which are accepted without question", [13]. Yet, for those members within Danish and South African organisations, there is a strong belief in equality amongst all members, with subordinates expecting more involvement in the decisions affecting their work. This is confirmed from the results, which show considerably lower power distance scores, at 3.89 and 4.11 respectively. Consequently, difficulties and misunderstandings may arise between English organizations and their acquired units from Denmark and South Africa.

TABLE I: CROSS BORDER M\&A INVOLVING FIRMS FROM ENGLAND

\begin{tabular}{lcc}
\hline \hline GLOBE Clusters & $\begin{array}{c}\text { Total number of } \\
\text { deals }\end{array}$ & Percentage \\
\hline Latin America & 69 & $4 \%$ \\
Confucian & 121 & $7 \%$ \\
Anglo Saxon & 744 & $43 \%$ \\
Africa & 76 & $4 \%$ \\
Southeast Asia & 131 & $8 \%$ \\
Middle East & 37 & $2 \%$ \\
Eastern Europe & 135 & $8 \%$ \\
Nordic & 146 & $8 \%$ \\
Latin Europe & 274 & $16 \%$ \\
Total & $\mathbf{1 7 3 3}$ & $100 \%$ \\
\hline \hline Note: All Cross Border M\&A between 2008 and 2012.
\end{tabular}

TABLE II: CULTURAL DIFFERENCES BETWEEN ENGLAND \& DENMARK AND SOUTH AFRICA

\begin{tabular}{lccc}
\hline \hline GLOBE Dimensions & $\begin{array}{c}\text { England } \\
\text { score }\end{array}$ & $\begin{array}{c}\text { Difference } \\
\text { : Denmark }\end{array}$ & $\begin{array}{c}\text { Difference: } \\
\text { South Africa }\end{array}$ \\
\hline Power Distance & 5.15 & 1.588 & 1.082 \\
Uncertainty Avoidance & 4.65 & 0.325 & 0.314 \\
$\begin{array}{l}\text { Human Orientation } \\
\text { Institutional }\end{array}$ & 3.72 & 0.518 & 0.053 \\
Collectivism & 4.27 & 0.281 & 0.014 \\
In-Group Collectivism & 4.08 & 0.303 & 0.176 \\
Assertiveness & 4.15 & 0.123 & 0.202 \\
Gender Egalitarianism & 3.67 & 0.068 & 0.160 \\
Future Orientation & 4.28 & 0.026 & 0.130 \\
$\begin{array}{l}\text { Performance } \\
\text { Orientation }\end{array}$ & 4.08 & 0.020 & 0.336 \\
\hline \hline
\end{tabular}

Note: Lower scores indicate greater similarities to English culture

\section{B. Uncertainty avoidance: Russia, Columbia and Greece}

Reference [14] defined the uncertainty avoidance dimension as a society's tolerance for uncertainty and ambiguity. Furthermore, it is an indication, to what extent members feel either uncomfortable or comfortable in unstructured situations.

From the individual practice scores from Table III, it is evident that England is a reasonably high uncertainty avoidance nation, with a score of 4.65. Additionally, from our sample, Russia, Columbia and Greece are amongst the nations in which England has extensive cultural difference. This is because these nations score notably lower in uncertainty avoidance, for example Greece's score of 3.39. Therefore, it is the English organizations who will feel a stronger threat from uncertain and unpredictable situations. Additionally, because of these strong threat perceptions, there is likely to be a greater need for rules and absolute truths. 
In contrast, for the Russian, Columbian and Greek firms, they are expected to embrace any form of uncertainty and risk, in environments where "innovation and pushing boundaries are likely to be encouraged", [15]. Nonetheless, regarding the matter of international acquisitions, these different levels in uncertainty avoidance should have important implication on acquisition performance.

TABLE III: CULTURAL DIFFERENCES BETWEEN ENGLAND AND RUSSIA, COLUMBIA AND GREECE

\begin{tabular}{lcccc}
\hline \hline \multicolumn{1}{c}{$\begin{array}{c}\text { GLOBE } \\
\text { Dimensions }\end{array}$} & England & $\begin{array}{c}\text { Differenc } \\
\text { e: Russia }\end{array}$ & $\begin{array}{c}\text { Difference: } \\
\text { Columbia }\end{array}$ & $\begin{array}{c}\text { Differenc } \\
\text { e Greece }\end{array}$ \\
\hline $\begin{array}{l}\text { Power } \\
\text { Distance }\end{array}$ & 5.15 & 0.137 & 0.168 & 0.063 \\
$\begin{array}{l}\text { Uncertainty } \\
\text { Avoidance }\end{array}$ & 4.65 & 3.133 & 1.166 & 1.588 \\
$\begin{array}{l}\text { Human } \\
\text { Orientation }\end{array}$ & 3.72 & 0.048 & 0.000 & 0.144 \\
$\begin{array}{l}\text { Institutional } \\
\text { Collectivism }\end{array}$ & 4.27 & 0.053 & 0.212 & 1.040 \\
$\begin{array}{l}\text { In-Group } \\
\text { Collectivism }\end{array}$ & 4.08 & 2.403 & 2.723 & 1.416 \\
$\begin{array}{l}\text { Assertiveness } \\
\text { Gender }\end{array}$ & 4.15 & 0.221 & 0.002 & 0.185 \\
$\begin{array}{l}\text { Egalitarianis } \\
\text { m }\end{array}$ & 3.67 & 0.160 & 0.000 & 0.036 \\
$\begin{array}{l}\text { Future } \\
\text { Orientation } \\
\text { Performance }\end{array}$ & 4.28 & 1.960 & 1.020 & 0.774 \\
Orientation & 4.08 & 0.476 & 0.020 & 0.774 \\
\hline Note: Lower scores indicate greater similarities to English culture
\end{tabular}

Accordingly, for organizational members within low UAI cultures, such as Russia, Columbia and Greece, they would be used to operate under a relaxed and informal environment, where they are highly tolerant of risks. Yet, under the acquisition of an English firm, they are likely to be exposed to multiple transitions, such as more formal rules and procedures, where tasks are greatly detailed and calculated. As a result of these differences, acquired members, although willingly, may struggle to adapt to this type of operational structure. Indisputably, this is likely to restrain the extent to which organization members develop strong relationships [16]. During culturally distant acquisition integration, key acquired employees may be less motivated to work under the new entity. Overall it is these types of differences which will impede integration efforts, negatively impacting on acquisition performance.

\section{In Group Collectivism: India, China, Turkey}

The dimension of In-group collectivism is most commonly used by researchers to comprehend the implications between different cultures [13].

Table IV shows that England is more of an individualistic nation than it is collective, with a practice score of 4.08. Therefore, "personal needs and attitudes are important determinants of social behavior" and "little distinction is made between in-groups and out groups", [17]. In contrast, nations such as China, India and Turkey have high levels in group collectivism, based on their scores at 5.92, 5.80 and 5.88. Therefore group loyalty is a key factor in these nations, where there tends to be a sense of family feeling and social responsibility [18]. Therefore for English organisations, acquiring companies from these nations, large differences on this dimension of national culture will exist, more extensively in India, where results confirm a cultural distance score with
England at 3.386.

TABLE IV: CULTURAL DIFFERENCES BETWEEN ENGLAND AND INDIA, CHINA AND TURKEY

\begin{tabular}{lcccc}
\hline \hline $\begin{array}{l}\text { GLOBE } \\
\text { Dimensions }\end{array}$ & $\begin{array}{c}\text { Englan } \\
\mathrm{d}\end{array}$ & $\begin{array}{c}\text { Differenc } \\
\mathrm{e}: \\
\text { India }\end{array}$ & $\begin{array}{c}\text { Difference: } \\
\text { China }\end{array}$ & $\begin{array}{c}\text { Differen } \\
\text { ce } \\
\text { Turkey }\end{array}$ \\
\hline $\begin{array}{l}\text { Power } \\
\text { Distance }\end{array}$ & 5.15 & 0.102 & 0.012 & 0.176 \\
$\begin{array}{l}\text { Uncertainty } \\
\text { Avoidance }\end{array}$ & 4.65 & 0.250 & 0.084 & 1.040 \\
$\begin{array}{l}\text { Human } \\
\text { Orientation }\end{array}$ & 3.72 & 0.723 & 0.410 & 0.048 \\
$\begin{array}{l}\text { Institutional } \\
\text { Collectivism }\end{array}$ & 4.27 & 0.012 & 0.250 & 0.058 \\
$\begin{array}{l}\text { In-Group } \\
\text { Collectivism } \\
\text { Assertiveness }\end{array}$ & 4.08 & 3.386 & 2.958 & 3.240 \\
$\begin{array}{l}\text { Gender } \\
\text { Egalitarianism }\end{array}$ & 3.67 & 0.593 & 0.384 & 0.608 \\
$\begin{array}{l}\text { Future } \\
\text { Orientation }\end{array}$ & 4.28 & 0.008 & 0.281 & 0.292 \\
$\begin{array}{l}\text { Performance } \\
\text { Orientation }\end{array}$ & 4.08 & 0.029 & 0.137 & 0.063 \\
\hline \hline $\begin{array}{l}\text { Note: Lower scores indicate greater similarities to English culture } \\
\text { Notion }\end{array}$ & & & 0.152 & 0.144 \\
\hline
\end{tabular}

For acquiring members within English organisations, they are more likely to maximize self-interest, without regard of the needs of members from the target firm. In contrast, the acquired, Indian, Turkish or Chinese firms as part of a collectivist culture will emphasize group goals, and aspirations of individuals tied to social obligations. In short, it is these differences in the mentality, values and customs with regards to behavior in the work environment of an acquisition, which are likely to lead to diverse viewpoints between different cultural groups, restraining the extent to which organisation members co-operate and work with each other. For these and other reasons, it is plausible that combining individualist with collectivist employees may inhibit the operations of the acquisition.

\section{RECOMMENDATIONS}

\section{A. Power Distance}

\section{1) Early and high level communication}

A lack of communication and dissimilar decision making practices, are key issues connected with differences in the power dimension. Therefore it seems highly appropriate for managers of English firms to, ensure they engage in early and high level communication with target firm, as it can aid in "establishing relationships, and more importantly help those employees feel appreciated", [13]. Reference [19] provides further justification by stating that, "besides the me issues, people want to know about the operations, systems and financial aspects of the newly formed organization, as these are matters that affect their personal situations". Therefore, it only seems logical that, to enhance acquisition success, with cultural integration, leaders must "share as much information early and often", [20]. As a result, managers of the acquiring English companies will not have to alter their existing high power management style, whilst at the same time, low power distance members from the target firm, can form an integral part of the new company. This gives good explanation for why high level communication is an appropriate strategy management could employ to deal with the implications of 
differences in power distance.

\section{B. Cross Company Teams}

Reference [21] states that for the success of international acquisitions cross functional teams are no longer sufficient and cross business collaboration is becoming increasingly popular. Cross company teams can be defined as the mixed collaboration between members of the acquiring and acquired firms, [22]. This recommendation is very nessacary for management in dealing with the rejection of knowledge transfer, identified from our research, as cross company teams "provide greater opportunities to and gain new perspectives and skills", from other individuals. This type of activity is likely to improve coordination, integration capabilities, and more importantly learning potential across national boundaries.

\section{Uncertainty Avoidance}

\section{1) Build and develop trust}

Trust is an important factor in business relations across national cultures, as it is a key "determinant of employees reactions or adversity to change, [19].With reference to our findings, trust and resistance to change are key implications originating from differences in the levels of uncertainty avoidance between partners in an acquisition. Therefore it is imperative for English managers to develop, trust amongst members from both parties in order to overcome these sociocultural barriers, whilst at the same time raising the confidence of all workforces involved.

\section{2) Cross - cultural training}

With reference back to the research, it is clear that the lack of trust extended to foreigners, particularly from those members who are high on uncertainty avoidance, is positively associated with cultural differences in uncertainty. With reference to [23], it details that by educating and training workforce about the culture of their partners and their ways of conducting business, can provide the necessary cultural understanding and intercultural sensitivity required to understand their colleagues' cultural values and preferences. This in turn will increase the potential for successful human integration, essential for long-term success.

\section{In Group - Collectivism}

\section{1) Reward systems}

It can be strongly argued that despite the differences in the levels of in group collectivism between acquirer English firms and their international targets, enhancing the commitment and mutual dependence of both parties is likely to help in managing the potential impact of distance in this cultural dimension. Reference [24] states that increasing mutual dependence can be done using reward systems. In this context, it can be argued that English managers should seek to base salary and reward systems not only on individual performances, but also on group performance. This would help "increase the degree of family feeling amongst those employees highly collective", [25]. Therefore regardless of the differences in this dimension, a reward scheme will encourage individual initiative and competition whilst simultaneously also showing care and recognition to group efforts. A practical example is from reference [26]; when
Volkswagen and Skoda merged, they developed many reward programs (which reflected team integration) where the best ideas where kept, irrelevant of which organization they derived from. Rewards systems encouraged thus the collaboration of employees from both firms. For this reason, reward schemes are effective in increasing openness of both firms to work through their differences and work together in achieving acquisition objectives.

\section{CONCLUSION}

From the research undertaken on the trends of English cross-border acquisitions, it became clear why establishing cultural distance levels with those nations they are highly active in was of great importance. The culture distance scores will provide management with at least an awareness, of those nations where problems may potentially occur. Secondly, from these differences, it enabled us investigate problems in differences from each dimension of national culture. Thus, this research has shown that for an international acquisition to have a better chance of success, English managers must recognize cultural differences, but more importantly allocate enough time and resources, in order to assimilate the host countries culture, with preparation to take place in advance of the deal.

\section{REFERENCES}

[1] Office for national statistics. (2013). Mergers and Acquisitions Involving UK Companies, Q4 2012. Newport: Office for National Statistics. [Online]. Available: http://www.ons.gov.uk/ons/dcp171778_302389.pdf.

[2] S. Grusgen, S. Kyriakides, and C. Venizelou, "Mergers \& acquisitions - success or failure? The role of corporate governance and strategic management in mergers and acquisitions with the examples of daimlerchrysler and Sony Ericsson," Ph.D. thesis, European University Cyprus.

[3] N. Helberger, "Clash of cultures, integrating copyright and consumer law," vol. 14, no. 6, pp. 23- 33, 2012.

[4] E. Vaara and G. Stahl, "The impact of organizational and national cultural differences on social conflict and knowledge," Transfer in International Acquisition, vol. no. 49, no. 1, pp. 1 - 27, 2011.

[5] LEXISNEXIS Group. (2013). Newswires and Press Releases. [Online]. Available:

http://www.lexisnexis.com/uk/nexis/search/newssubmitForm.do.

[6] S. Jarvenpaa and D. Leidner. (2012). Communication and Trust in Global Virtual Teams. [Online]. Available: http://hyperion.math.upatras.gr/commorg/jarvenpaa/.

[7] R. Brislin and E. Kim, "Cultural diversity in people's understanding and uses of time," Applied Psychology, vol. 52, no. 3, pp. 363-382, 2003.

[8] B. Bresman, J. Birkinshaw, and R. Nobel, "Knowledge transfer in international acquisitions," Journal of International Business Studies, pp. 439-462, 1999

[9] R. V. Wijk, J. Jansen, and A. Lyles, "Inter-and intra-organizational knowledge transfer: A meta-analytic review and assessment of its antecedents and consequences," Journal of Management Studies, vol. no. 45 , no. 4 , pp. 830-853, 2008.

[10] Wisegeek. (2013). What is Absorptive Capacity? [Online]. Available at: http://www.wisegeek.com/what-is-absorptive-capacity.htm.

[11] R. House and P. Hanges, Culture, Leadership and Organisations: The Globe Study of 62 Societies, London: Sage Publications, 2004.

[12] R. Cook. (2013). Global Training - Cultural Differences and Their Implications for Trainers. [Online]. Available: www.global-excellence.com/global-training.php.

[13] M. Kvantaliani and O. Klimina, "Implications of cross-cultural communication in business: A strategy of Swedish small enterprise ImseVimse and its international distributors and retailers," M. A. thesis, Gotland University, Sweden, 2011.

[14] J. Lundborg, "Cultural distance and international acquisition performance," M. A. thesis, Upsala University, Sweden, 2008. 
[15] Kwintessential. (2012). How Culture Ended the Daimler - Benz Chrysler merger [Online]. Available: http://www.kwintessential.co.uk/resources/daimlerbenz-chrysler-merg er.html.

[16] Y. Luo, "Antecedents and consequences of personal attachment in cross-cultural cooperative ventures," Administrative Science Quarterly, vol. 46, no. 2, pp. 177-201, 2001.

[17] GROVEWELL LLC. (2004). Worldwide Differences in Business Values and Practices: Overview of GLOBE Research Findings. California: Harcourt Brace and World Publishing Company. [Online]. Available: http://www.grovewell.com/pub-GLOBE-dimensions.html.

[18] H. Makhlouk and O. Shevchuck, "The Importance and Influence of the Corporate Culture in a Merger and Acquisition Context," M. A. thesis, University of Kalmar, Sweden, 2008.

[19] A. Grankvist, C. Kollberg, and A. Persson, "Implementation of Organisational Culture Following a Merger: Case Studies of Arla foods and Stora Enso," M. A. thesis, Lulea University of Technology, Sweden, 2004.

[20] T. Bednarz. (2012). The Concept Of Change Means Leaders Must Communicate. [Online]. Available: http://ezinearticles.com/?The-Concept-Of-Change-Means-Leaders-M ust-Communicate $\& i d=7544381$.

[21] L. Anderson. (2012). Case Study in Cross-Company Project Collaboration. [Online]. Available: http://www.projecttimes.com/lisa-anderson/case-study-in-cross-comp any-project-collaboration.html.

[22] S. Francis and J. Stearn. (2011). Reaping the rewards of cross business collaboration in mergers and acquisitions. [Online]. Available at:

http://www.iveybusinessjournal.com/topics/strategy/reaping-the-rewa rds-of-cross-business-collaboration-in-mergers-and-acquisitions\#.UW aXppMskVp.

[23] COMMUNICAID. (2012). International Mergers and Acquisitions: Maximising the Cultural Benefits. [Online]. Available: http://www.communicaid.com/cross-cultural-training/blog/cross-cultu ral-training/international-mergers-and-acquisitions-maximising-the-cu ltural-benefits/.
[24] R. Zoon, "Culture: The problem child during a merger and acquisition," M. A. thesis, 2010

[25] P. Clerc, "Managing the cultural issue of merger and acquisition: The Renault Nissan case," M. A. thesis, Goteborg University, Sweden, 1999.

[26] S. Regani, "Volkswagen's acquisition of Skoda auto," A Central European Success Story, Center for Management Research, 2007.

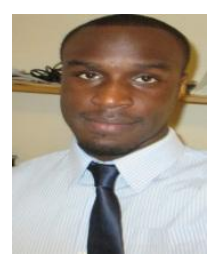

Michael Akanni graduated from Nottingham Trent University, Nottingham, UK. He was studying BA Management and Accounting \& Finance 2009-2013 at Nottingham Business School, Nottingham Trent University, Nottingham, UK.

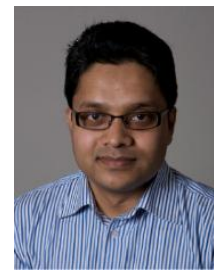

Mohammad F. Ahammad is a senior lecturer at Nottingham Business School, Nottingham Trent University, Nottingham, UK. Dr. Ahammad is an active researcher in the field of international business and finance, in particular, in the area of cross border mergers and acquisitions ( $\mathrm{M}$ and $\mathrm{As}$ ) on which he holds a $\mathrm{PhD}$ degree from the University of Sheffield. Dr. Ahammad has published his research studies in International Business Review, International Studies of Management \& Organization, European Journal of International Management, and others. He currently serves as a guest-editor for the special issue on cross-cultural collaboration at International Studies of Management \& Organization and co-guest editor for the special issue on Strategic Talent Management at Thunderbird International Business Review. His current research projects include: pre-acquisition evaluation and cross border acquisition performance, post-acquisition issues and cross-border acquisition performance. 